\title{
Comparison of Biochemical, Antimicrobial and Cytotoxic Activities of Different Propolis Samples from Malatya and Bilecik
}

\author{
MERVE KESKIN ${ }^{1 *}$, SEMIRAMIS KARLIDAG ${ }^{2}$, OZGUR YILMAZ $^{3}$, ERAY TATLICI ${ }^{3}$, \\ ERCAN KARABULUT ${ }^{4}$, ELIF APOHAN ${ }^{2,3}$, OZFER YESILADA $^{3}$ \\ ${ }^{1}$ Vocational School of Health Service, Bilecik Seyh Edebali University, Bilecik, Turkey \\ 2 Malatya Turgut Ozal University, Malatya, Turkey \\ ${ }^{3}$ Faculty of Science, Inonu University, Malatya, Turkey \\ ${ }^{4}$ Faculty of Medicine, Ankara Yildırım Beyazit University, Ankara, Turkey
}

\begin{abstract}
Propolis is a resinous natural mixtures collected and produced by honey bees. It is rich in essential oils and phenolic components so it has high levels of antioxidant, antimicrobial, antiinflammatory and anti-tumoral activity. In this study the biochemical activity of propolis extracts were determined. The antimicrobial activity and cytotoxic activity of the extracts of the nine different propolis samples were invastigated. Their antimicrobial activities were tested by microdillution metod and define as minimum inhibitory concentration (MIC). Chemical composition of extracts was determined by using GC-MS equipment. Total phenolic content and antioxidant activity of the extracts was measured. Antimicrobial and cytotoxic activity of the extracts was carried out as well. All of the extracts showed antimicrobial activity on bacteria and yeasts used. Extracts had generally lower MIC values on yeasts. Therefore, yeasts were detected as more susceptible against the propolis extracts than the bacteria. Cytotoxic activity of extract were determined aganist A549 and Beas $2 B$ cell lines and IC50 values were calculated. Ma-Arapgir had the highest cytotoxic activity on A549 and Beas $2 B$. They were determined as 6.72 and $26.44 \mathrm{mg} / \mathrm{mL}$, respectively. It could be concluded that propolis extracts have antimicrobial and cytotoxic activity thus, propolis could be used in the treatment of cancer.
\end{abstract}

Keywords: Propolis, A549, Beas2B, antimicrobial activity, cytotoxic activity

\section{Introduction}

Apitherapy defined as a treatment made with bee products like honey, propolis bee venom etc. They have promising benefits on human health. Honey bee products have been used since ancient times. Because of the adverse effects of modern drugs and developed antibiotic resistance, there has been an increasing trend towards the usage of traditional and natural substances for treatment. Propolis has gained significant importance in such purposes due to its rich biologically active components. It is a natural mixture collected by honeybees from bud exudates of plants. Generally, raw propolis consists of $40-50 \%$ resin, $20-30 \%$ wax, $5-10 \%$ essential oils, $1-5 \%$ pollen, various phenolic compounds and organic acids. Types and amount of both volatile and phenolic constituents vary according to the source of resin. Although the physical and chemical properties of propolis vary according to obtained geographical region (resin source), it exhibits high antioxidant, antimicrobial, anti-inflammatory and antitumor properties due to its essential oils and polyphenols [1-3].

Antibiotic resistance is a common problem all around the world. Because of this problem, there is an increasing demand for natural antimicrobial agents. Having diverse biologically active constituent such as phenolic acids, flavonoids and terpenes makes propolis promising agents to overcome this problem. As mentioned above, even propolis samples differ in chemical composition they possess similar biological activity. So it is important to determine chemical composition of different propolis

\footnotetext{
*email: merveozdemirkeskin@gmail.com
} 
samples to clarify the relationship between biological activity and chemical composition. This determination could make way for identification of new antimicrobial agent present in propolis.

In this study, raw propolis samples were collected from Malatya and Bilecik city in Turkey. Biochemical characterization, antimicrobial and anticancer effects of propolis samples were determined. Results were compared with each other.

\section{Materials and methods}

Propolis samples were supplied from local bee keepers in Bilecik city (Koyunköy, Vezirhan, city centre and Sogut district) and Malatya city (Arapgir, Akçadağ, Battalgazi, Doganyol and Dogansehir district) Turkey in 2018. Ethanol, methanol and Gallic acid were purchased from sigma Aldrich, USA. All other reagents were analytical grade. Escherichia coli ATCC 25922, Pseudomonas aeruginosa ATCC 27853, Staphylococcus aureus ATCC 29213, Candida albicans ATCC 90028 and Candida trophicalis were used as test organisms to determine the antimicrobial actvity of various propolis samples.

\subsection{Preparation of propolis extracts}

Extraction of propolis samples with ethanol $(70 \% \mathrm{v} / \mathrm{v})$ was carried out by simple maceration technique separately. 1:10 (g/v) ratio was used for the extraction. Frozen propolis sample was powdered by grinding and $3 \mathrm{~g}$ of this fine powder was mixed with $30 \mathrm{~mL}$ of ethanol solution. Extraction was carried out for $48 \mathrm{~h}$ on a magnetic stirrer under constant stirring at $150 \mathrm{rpm}$. Finally, mixtures were separately filtered and filtrates were stored at $+4{ }^{\circ} \mathrm{C}$.

\subsection{Determination of balsam \%}

Balsam is usually defined as the alcohol soluble fraction of propolis. In order to determine the ratio of balsam, $2 \mathrm{~mL}$ of propolis extract was evaporated and the amount of resulted solid was quantified until reaching a constant weight. The amount of balsam of the extract was calculated and expressed as a percentage value [4].

\subsection{Determination of total phenolic and flavonoid content}

Total phenolic content of ethanol propolis extracts (EPE) was determined by using Folin-Ciocalteu method [5,6] Gallic acid as standard. Results were expressed as mg GAE/mL. Total flavonoid content of the samples was determined by using aluminum chloride method [7] quercetin as standard. Results were expressed as $\mathrm{mg} \mathrm{QE} / \mathrm{mL}$.

\subsection{GC-MS analysis}

Main chemical composition of ethanol propolis extract (EPE) was determined with Gas chromatography coupled with mass spectrometry. Samples were analyzed after derivatization with bis(trimethylsilyl)-trifluoro-acetamide (BSTFA) to clarify the chemical composition. Shortly, propolis extracts were dried by using rotary evaporator and $5 \mathrm{mg}$ of dried residue was mixed with $50 \mu \mathrm{L}$ of dry pyridine and $75 \mu \mathrm{L}$ of BSTFA. This reaction mixture was heated at $80^{\circ} \mathrm{C}$ for $20 \mathrm{~min}$. GC-MS analysis was applied with an Agilent 7890A GC system equipped with HP5-MS capillary column (30 m* 0.25 $\mathrm{mm} * 0.5 \mathrm{~mm})$. The oven temperature was programmed from 75 to $325^{\circ} \mathrm{C}$ at a rate of $5^{\circ} \mathrm{C} / \mathrm{min}$, and a $15 \mathrm{~min}$ hold at $325^{\circ} \mathrm{C}$. Helium was used as a carrier gas at a flow rate of $0.8 \mathrm{~mL} / \mathrm{min}$. The split ratio was $1: 50$, the injector temperature $300^{\circ} \mathrm{C}$, and the ionization voltage $70 \mathrm{eV}$ [8]. Identification of the compounds was performed using commercial libraries as wiley [8].

\subsection{Determination of antimicrobial Aactivity}

Antimicrobial activity was tested by the microdilution method. The inocula were prepared from $24 \mathrm{~h}$ cultures. The turbidity of the cultures was firstly adjusted by $0.5 \mathrm{McFarland}$ standard and then the inocula were prepared by diluting these cultures. Serial dilutions of propolis were prepared in 96 well 
plates containing Muller Hinton broth for bacteria and RPMI-1640 for yeasts. After inoculation, the plates were incubated for $24 \mathrm{~h}-48 \mathrm{~h}$ at $37^{\circ} \mathrm{C}$. The lowest concentration of antimicrobial agent that inhibits the growth of microorganism was defined as the minimum inhibitory concentration (MIC). Gentamicin and fluconazole were used as strandard antibiotics against bacteria and yeasts, respectively [9].

\subsection{Determination of cytotoxic activity}

The human cancer lines, lung adenocarcinoma (A549) and healthy human lung bronchial epithelium cells (BEAS-2B) were used for in this study. The cells were maintained in DMEM growth medium containing $10 \%$ fetal bovine serum and $1 \%$ penicillin/streptomycin at $37^{\circ} \mathrm{C}$ in $5 \% \mathrm{CO}_{2}$. Cells were counted after trypsin detachment, seeded in 96-well plates and incubated for $24 \mathrm{~h}$ at $37^{\circ} \mathrm{C}$ with $5 \% \mathrm{CO}_{2}$ to allow cell attachment [10].

Before treatment with propolis the A549 and BEAS-2B cells were plated in 96 well plates $\left(5 \times 10^{3}\right.$ cells/well) for $24 \mathrm{~h}$ to allow the attachment of the cells of the plate. They incubated at $37^{\circ} \mathrm{C}$ in a humidified incubator with $5 \% \mathrm{CO}_{2}$ during the experiment. Then, the tested different propolises were added to obtain the final concentration in the range of $(0-100 \mathrm{mg} / \mathrm{mL})$ and the cells were incubated for 24, 48 and $72 \mathrm{~h}$. After incubation, the medium was removed and the wells were treated with $100 \mu \mathrm{L}$ of $5 \mathrm{mg} / \mathrm{mL}$ MTT and incubated for $4 \mathrm{~h}$ at $37^{\circ} \mathrm{C}$. Then, $100 \mu \mathrm{L}$ of solubilizing solution, DMSO, were added to each well and the produced purple solution was quantified colorimetrically at $540 \mathrm{~nm}$ [11]. Twelve wells were used for every concentration was repeated in twelve wells and $\mathrm{IC}_{50}$ values $(\mathrm{mg} / \mathrm{mL})$ were defined as the compound concentrations reducing absorbance to $50 \%$ of control values. Cisplatin was also used as a control agent.

\section{Results and discussions}

The amount of balsam determined in Bilecik and Malatya propolis ranged between $10.3 \%$ and 40.6\%. Results were summarized in Table 1. It was determined that total phenolic content ranged between 5.42 to $35.46 \mathrm{mg} \mathrm{GAE} / \mathrm{mL}$ and maximum flavonoid content was determined as $4.69 \mathrm{mg}$ $\mathrm{QE} / \mathrm{mL}$. Results were summarized in Table 1.

Table 1. Total phenolic and flavanoid content of propolis samples

\begin{tabular}{ccc}
\hline Propolis & $\begin{array}{r}\text { Total Phenolic Content } \\
\text { mg/mL GAE }\end{array}$ & $\begin{array}{c}\text { Total Flavanoid Content } \\
\text { mg/mL QE }\end{array}$ \\
\hline Ma-Arapgir & $13.97 \pm 0.48$ & $1.73 \pm 0.03$ \\
Ma-Akçadağ & $10.14 \pm 0.21$ & $2.11 \pm 0.02$ \\
Ma- Doğanyol & $5.42 \pm 0.20$ & $0.83 \pm 0.01$ \\
Ma- Doğanşehir & $8.61 \pm 0.33$ & $1.06 \pm 0.01$ \\
Ma- Battalgazi & $16.0 \pm 0.51$ & $2.36 \pm 0.02$ \\
Bile-Merkez & $31.07 \pm 1.18$ & $4.76 \pm 0.01$ \\
Bile-Merkez2 & $28.06 \pm 0.96$ & $5.11 \pm 0.03$ \\
Bile- Koyunköy & $21.65 \pm 0.88$ & $2.54 \pm 0.02$ \\
Bile- Vezirhan & $35.46 \pm 1.51$ & $3.62 \pm 0.03$ \\
\hline
\end{tabular}

GC-MS analysis was performed to investigate the chemical composition of the propolis extracts. As a result of GC-MS analysis, aldehydes, aliphatic acid and esters, alcohols, hydrocarbons, carboxylic 
acid esters, ketones, terpenes, fatty acids and other compounds were detected in propolis samples. Identified compounds were summarized in Table 2.

Table 2. GC/MS results of propolis samples

\begin{tabular}{|c|c|c|c|c|c|c|c|c|c|}
\hline & $\begin{array}{c}\text { Ma- } \\
\text { Akçadağ }\end{array}$ & $\begin{array}{c}\text { Ma- } \\
\text { Arapgir }\end{array}$ & $\begin{array}{c}\text { Ma- } \\
\text { Battalgazi }\end{array}$ & $\begin{array}{c}\text { Ma- } \\
\text { Doğanşehir }\end{array}$ & $\begin{array}{c}\text { Ma- } \\
\text { Doğanyol }\end{array}$ & $\begin{array}{c}\text { Bile- } \\
\text { Vezirhan }\end{array}$ & $\begin{array}{c}\text { Bile- } \\
\text { Koyunköy }\end{array}$ & Bile-Merkez & $\begin{array}{c}\text { Bile- } \\
\text { Merkez2 }\end{array}$ \\
\hline Ferulic Acid & 0.965 & - & 1.47 & 0.62 & 0.091 & 1.62 & 0.98 & 1.83 & 1.12 \\
\hline $\begin{array}{l}\text { 3-Methyl-2- } \\
\text { Butenyl } \\
\text { Isoferulate }\end{array}$ & - & & & - & - & 0.023 & 0.015 & 0.027 & 0.010 \\
\hline Caffeic Acid & 2.431 & 1.273 & 1.33 & - & 0.169 & 2.061 & 1.981 & 2.162 & 1.805 \\
\hline $\begin{array}{c}\text { Hydrocinnamic } \\
\text { Acid }\end{array}$ & 0.02 & & - & - & - & - & 0.962 & 0.823 & 0.925 \\
\hline $\begin{array}{l}\text { 4-Hydroxy,3- } \\
\text { Methoxycinnami } \\
\text { c Acid }\end{array}$ & 0.59 & 0.926 & - & - & - & 0.190 & & & \\
\hline $\begin{array}{c}\text { P-Methoxy } \\
\text { Cinnamic Acid }\end{array}$ & 0.169 & & 0.324 & - & - & 1.02 & 0.76 & 0.81 & 1.02 \\
\hline Benzoic Acid & - & 0.048 & - & - & 0.081 & - & 0.063 & 0.051 & 0.050 \\
\hline $\begin{array}{c}\text { 2-Propenoic } \\
\text { Acid }\end{array}$ & - & & - & - & - & 3.310 & & & \\
\hline Succinic Acid & 1.851 & & - & - & - & - & & & \\
\hline Malic Acid & 0.500 & & - & 1.15 & - & - & & & \\
\hline Palmitic Acid & 0.73 & 0.329 & - & - & - & - & 0.68 & 0.27 & 0.33 \\
\hline Stearic Acid & 0.139 & & - & - & - & - & 0.112 & 0.098 & 0.118 \\
\hline Linalool Oxide & 0.057 & & - & - & - & - & & & \\
\hline Oleic Acid & - & 0.832 & - & - & 0.247 & - & 0.451 & 0.375 & 0.332 \\
\hline $\begin{array}{c}\text { Octadecenoic } \\
\text { Acid }\end{array}$ & - & 0.280 & - & - & - & 0.791 & & & \\
\hline $\begin{array}{c}\text { Butanedioic } \\
\text { Acid }\end{array}$ & - & 0.0514 & 1.92 & 3.497 & 0.720 & 0.77 & & & \\
\hline $\begin{array}{c}\text { Hexadecanoic } \\
\text { Acid }\end{array}$ & - & & - & 0.52 & 0.115 & 0.158 & & & \\
\hline $\begin{array}{c}\text { Benzeneacetalde } \\
\text { hyde } \\
3,5,7-\end{array}$ & - & 0.04 & - & - & - & - & & & \\
\hline $\begin{array}{c}\text { Trihydroxy } \\
\text { Flavone }\end{array}$ & - & 0.474 & - & - & - & - & 0.114 & 0.089 & 0.341 \\
\hline Galactitol & - & 0.18 & - & - & - & - & & & \\
\hline L-Valine & - & - & - & - & 0.035 & - & & & \\
\hline $\begin{array}{l}\text { L-Proline } \\
\text { Galacturonic }\end{array}$ & - & - & - & - & 0.093 & 0.026 & & & \\
\hline Acid & - & - & - & - & 0.07 & - & & & \\
\hline Fructose & - & - & - & - & 0.248 & - & 0.302 & - & 0.175 \\
\hline Sorbose & 2.239 & - & 1.93 & - & - & - & & & \\
\hline D-Galactose & 0.029 & - & - & - & 0.087 & - & 0.021 & 0.065 & 0.041 \\
\hline Mannose & - & - & 1.712 & 0.021 & - & - & 1.152 & 0.986 & 1.238 \\
\hline Maltose & - & - & - & 1.33 & 0.55 & - & & & \\
\hline Sucrose & - & - & - & 18.483 & 40.01 & - & & & \\
\hline Arabinonic Acid & - & - & - & - & 0.424 & - & & & \\
\hline Benzenamine & - & - & - & 0.022 & - & - & & & \\
\hline
\end{tabular}

MICs of ethanol extracts of nine different propolis samples were given in Table 1. The propolis samples used showed high antimicrobial activity on bacteria and yeasts. These samples had higher antimicrobial activity against $P$. aeruginosa, $C$. albicans and $C$. trophicalis than $E$. coli and $S$. aureus. C. albicans was detected as the most susceptible bacteria Results were summarized in Table 3. It is reported that propolis has quite good antimicrobial activity and our result are compatible with the literature [12]. 
Table 3. MIC values $(\mathrm{mg} / \mathrm{mL})$ of propolis samples

\begin{tabular}{cccccc}
\hline Propolis & E. coli & P. aeruginosa & S. aureus & C. albicans & C. tropicalis \\
\hline Ma-Arapgir & 25 & 1.56 & 1.56 & 0.049 & 0.0975 \\
Ma-Akçadağ & 6.25 & 1.56 & 3.125 & 0.0975 & 0.195 \\
Ma-Doğanşehir & $>25$ & 1.56 & 3.125 & 0.0975 & 0.195 \\
Ma-Doğanyol & $>25$ & 3.125 & 3.125 & 0.195 & 0.78 \\
Ma-Battalgazi & 25 & 0.78 & 1.56 & 0.098 & 0.195 \\
Bile-Merkez & 6.25 & 0.39 & 1.56 & 0.097 & 0.0975 \\
Bile-Merkez2 & 6.25 & 0.78 & 1.56 & 0.0975 & 0.0975 \\
Bile-Koyunköy & 12.5 & 1.56 & 3.125 & 0.0975 & 0.195 \\
Bile-Vezirhan & 12.5 & 0.39 & 1.56 & 0.0975 & 0.78 \\
Gentamicin & 0.00078 & 0.00039 & 0.00312 & - & - \\
Flucanozole & - & - & - & 0.00039 & 0.00039
\end{tabular}

In order to investigate the cytotoxic effects of 9 different propolis samples the cells (A549 and BEAS2B) were incubated with increasing concentrations $(0-100 \mathrm{mg} / \mathrm{mL})$ of propolis samples for 24 , 48 and $72 \mathrm{~h}$, and then subjected to a MTT assay. The cytotoxicity results, expressed as $\mathrm{IC}_{50}$ (concentration required to inhibit tumor cell proliferation by $50 \%$ ), are listed in Table 4 . Among the 9 propolis samples tested, propolis sample from Malatya Arapgir had the highest cytotoxic activity on A549. $\mathrm{IC}_{50}$ values of its on A549 and BEAS-2B were determined as and 6.72 and $26.44 \mathrm{mg} / \mathrm{mL}$, respectively. Results were summarized in Table 4.

Table 4. $\mathrm{IC}_{50}(\mathrm{mg} / \mathrm{mL})$ values of propolis samples on A549 cells and Beas2B cells

\begin{tabular}{|c|c|c|c|c|c|c|}
\hline \multirow{2}{*}{$\begin{array}{c}\text { MTT } \\
\mu \mathrm{g} / \mathrm{mL} \\
\text { (IC } \\
\text { (I0 values) }\end{array}$} & \multicolumn{3}{|c|}{ A549 } & \multicolumn{3}{|c|}{ Beas2B } \\
\hline & 24. saat & 48. saat & 72. saat & 24. saat & 48. saat & 72. saat \\
\hline Ma- Arapkir & 9.24 & 7.98 & 6.72 & 8.26 & 21.72 & 26.44 \\
\hline Ma- Akçadağ & 38.33 & 45.92 & 26.05 & 61.31 & $54.87^{\circ}$ & 65.13 \\
\hline Ma-Doğanșehir & 43.84 & 58.12 & 52.49 & 54.67 & 65.51 & 84.22 \\
\hline Ma- Doğanyol & - & - & 79.14 & - & - & - \\
\hline Ma- Battalgazi & 49.92 & 30.22 & 41.12 & 51.85 & 43.13 & 26.61 \\
\hline Bile-Merkez & 46.54 & 23.07 & 29.13 & 52.67 & 56.67 & 40.93 \\
\hline Bile-Merkez2 & 6.42 & 8.75 & 19.59 & 14.71 & 15.53 & 22.7 \\
\hline Bile-Koyunköy & 5.23 & 10.32 & 7.8 & 14.3 & 14.68 & 19.32 \\
\hline Bile- Vezirhan & 11.96 & 13.46 & 14.01 & 14.93 & 16.40 & 21.69 \\
\hline
\end{tabular}

Propolis, which is called bee glue or bee gum, is a natural mixture of plant origin used by honey bees to protect their hives against all kinds of threats and hazards. Due to its high antimicrobial properties, human beings used propolis as a natural antibiotic at first. Later with the emergence of high antioxidant, anti-inflammatory, antitumoral and immunoprotective properties, propolis became an indispensable natural product of phytotherapy and apiterapy [13-15]. The chemical composition of propolis is very complex and its color, odor and medicinal characteristics are different as the composition varies depending on the plant, region, season and colony. Therefore, the biological activity of propolis collected from different regions also varies [16-19].

It was reported high amounts of balsam express high phenolic compounds and low waxes $[4,8]$. Indeed, it was stated that crude propolis contains between $40 \%$ and $60 \%$ balsam [4]. Since it is not 
possible to fully elucidate the phenolic contents of the plant extracts, the phenolic content is expressed in terms of total phenolic content. Total phenolic components are measured by spectrophotometric method based on color complex formation with Folin-Ciocalteu reagent. The high amount of phenolic content refers to high antioxidant activity while at the same time high biological activity. It is seen that total phenolic content of ethanol extracts of Bilecik and Malatya propolis varies between 5.42- 35.46 $\mathrm{mg}$ GAE / $\mathrm{mL}$ (Table 1). Total flavonoid content was maximally determined as $4.46 \mathrm{mg} \mathrm{QE} / \mathrm{mL}$. In a study, it was reported that total phenolic content of crude propolis samples obtained from Brazil ranged between $8.8 \%$ and $13.7 \%$ and flavonoid content was minimum $0.35 \%$ and maximum $2.7 \%$ [19]. It was reported that the amount of total phenolic content in Anatolian propolis ranged between 10.6-178 mg GAE/g and the total amount of phenolic content increased with increasing amount of balsam [20]. It was reported that total amount of phenolics ranged between 115 to $210 \mathrm{mg} \mathrm{GAE} / \mathrm{g}$ for different Turkish propolis samples [3]. It reported that total phenolic content ranged between 1.2 to $15.6 \mathrm{mg} / \mathrm{g}$ for Turkish chestnut propolis [21]. It is clear that total phenolic content for propolis samples obtained from different regions of Turkey varies in wide range.

GC-MS analysis was performed to investigate the chemical composition of the propolis extracts (Table 2). As a result of GC-MS analysis, aldehydes, aliphatic acid and esters, alcohols, hydrocarbons, carboxylic acid esters, ketones, terpenes, fatty acids and other compounds were detected in propolis samples. It is clear that our results are consistent with the literature data [21-23]. There are various studies on antimicrobial activity of propolis and it was reported that it shows different antimicrobial activity due to their composition and origin [24-28].

We found that all propolises have less cytotoxic effect BEAS2B cell line than A549 cell line showed in Tablo 4. It is tested that the combination of lower concentrations of antitumor drugs (carboplatin - CARB, doxorubicin - DOX, and methotrexate - MET) with propolis was investigated against canine osteosarcoma (spOS-2) and mesenchymal stem cells (MSC) in vitro [29]. They found that propolis alone exerted no cytotoxic action against spOS-2 cells, whereas CARB (400, 200 and 100 $\mu \mathrm{mol} / \mathrm{l})$ exhibited the highest cytotoxic effects comparing to DOX and MET. It was done that Cuban red propolis for test cytotoxic effect of $\mathrm{CP}$ against MDA MB-231 cell line by [30]. It was found that $\mathrm{CP}$ has cytotoxic effect on this cell line. It was determined that Malta propolis has cyctotoxic activity [31]. It is reported that only a few kilometers at different distances and at different times of the year collected from different regions propolis showed significant changes in cytotoxicity, which is due to the total content of phenolics. It was determined that the area where the propolis was collected and the season were effective on the bioactivity of propolis products. Chemical properties of propolis samples collected from Hatay region and three different cancer lines (A549; human lung adenocarcinoma, HeLa; human cervical carcinoma, A498 human kidney carcinoma) to determine the proliferative effects on a study [22] benzoic acid, phenylethyl alcohol and 9- octadecenoic acid have been shown to show significant antiproliferative effects against human lung adenocarcinoma (A549), human cervical carcinoma (HeLa) and human kidney carcinoma (A498) cells. It was emphasized that these components can be used as promising propolis compounds for new drug development.

\section{Conclusions}

Because of the adverse effects of modern drugs and developed antibiotic resistance, there has been an increasing trend towards the usage of traditional and natural substances for treatment. Propolis has gained significant importance in such purposes due to its rich biologically active components. It is a natural mixture collected by honeybees from bud exudates of plants. In this study, it is clear that propolis has effect on A549 and Beas2B cell lines and has antimicrobial activity. Although its chemical composition depends on botanical origin, propolis has promising benefits on human health.

Acknowledgments. A549 cells were obtained from Prof. Dr. Fikrettin Sahin (Yeditepe University, Department of Genetics and Bioengineering, Istanbul/Turkey). 


\section{References}

1. AHN, M.R., KUMAZAWA, S., USUI, Y., NAKAMURA, J., MATSUKA, M., ZHU, F., NAKAYAMA, T., Antioxidant Activity and Constituents of Propolis Collected in Various Areas of China, Food Chemistry, 101, 2007, 1383-1392.

2. LI, F., AWALE, S., TEZUKA, Y., KADOTA, S. BIOORG., Cytotoxic Constituents From Brazilian Red Propolis and Their Structure-Activity Relationship, Med. Chem., 16, 2008, 5434-5440.

3. AliYAZICIOGLU, R., SAHIN, H., ERTURK, O., ULUSOY, E., KOLAYLI, S., Properties of phenolic composition and biological activity of propolis from Turkey International Journal of Food Properties, 16, 2013, 277-287.

4.POPOVA, M., GIANNOPOULOU, E., SKALICKA-WO’ZNIAK, K., GRAIKOU, K., WIDELSKI, J.,BANKOVA, V., KALOFONOS, H., SIVOLAPENKO, G., GAWEŁ-B، EBEN,K., ANTOSIEWICZ, B., CHINOU, I., Characterization and Biological Evaluation of Propolis from Poland, Molecules, 22, 2017,1159 .

5.SINGLETON V.L., ROSSI J.A., Colorimetry of Total Phenolics with PhosphomolybdicPhosphotungstic Acid Reagents, American Journal of Enology and Viticulture, 16, 1965, 144-158.

6.SINGLETON, V.L., ORTHOFER, R., LAMUELA-RAVENTOS, R.M., Analysis of Total Phenols and Other Oxidation Substrates and Antioxidants by Means of Folin-Ciocalteu Reagent, Methods in Enzymology, 299, 1999, 152-178.

7.FUKUMOTO L.R., MAZZA, G., Assessing antioxidant and prooxidant activities of phenolic compounds, Food Chemistry, 48, 2000, 3597-3604.

8. BANKOVA, V., DE CASTRO, S., MARCUCCI, M., Propolis: recent advances in chemistry and plant origin, Apidologie, Springer Verlag, 31, 2000, 3-15.

9. APOHAN, E., YILMAZ, U., YILMAZ, O., SERINDAG, A., KÜÇÜKBAY, H., YEŞILADA, Ö., BARAN, Y., Synthesis, cytotoxic and antimicrobial activities of novel cobalt and zinc complexes of benzimidazole derivatives, Journal of Organometallic Chemistry, 828, 2017, 52-58.

10. GÖKBULUT, A.A., APOHAN, E., BARAN, Y., Resveratrol and quercetin-induced apoptosis of human 232B 4 chronic lymphocytic leukemia cells by activation of caspase-3 and cell cycle arrest, Hematology, 18, 2018, 144.

11. BONVEHI, J.S., COLL, F.V., JORDA, R.E., The Composition Active Components and Bacteriostatic Activity of Propolis in Dietetics. JAOCS, 71, 1994, 5, 18-25.

12. BUZIA, O.D., MARDARE, N., DRAGOMIR, R., MIULESCU, M., TATU, A.L., Pharmaceutical Forms with Basil and Propolis to the Benefit of the Oral Cavity. Formulation, preparation and microbiological analysis, Rev. Chim., 70(1), 2019, 343-349.

13. POPOVA, M., TRUSHEVA, B., BANKOVA, V., Content of Biologically Active Compounds in Bulgarian Propolis: a Basis for its Standardization, Bulgarian Chemical Communications, 49, 2017, 115-120.

14. DIAS, L.G., PEREIRA, A.P., ESTEVINHO, L. M., Comparative Study of Different Portuguese Samples of Propolis: Pollinic, Sensorial, Physicochemical, Microbiological Characterization and Antibacterial Activity, Food and Chemical Toxicology, 50, 2012, 4246- 4253.

15. SCHMIDT, J.O., BUCHMANN, S.L., Other products of the hive. In: The Hive and the Honeybee J.M. Graham, ed. Dadant \& Sons, Hamilton, Illinois, USA. P, 1992, 927-988.

16. HOUGHTON, P.J., RAMAN, A., Laboratory Handbook for Fractionation of Natural Extracts Chapman and Hall, London, 1998, 199.

17. KENMORE, P., KRELL, R., Global perspectives on pollination in agriculture and agroecosystem management Agriculture, with Emphasis on Bees, 1998, 7-9.

18. WOISKY, R.G., SALATINO, A., Analysis of propolis: some parameters and procedures for chemical quality control, Journal of Apicultural Research, 37(2), 1998, 99-105.

19. KESKIN, M., KOLAYLI, S., Standardization of propolis, Is it possible?, U. Bee J., 18 (2), 2018, 101-110. 
20. SARIKAYA, A.O., ULUSOY, E., ÖZTÜRK, N., TUNÇEL, M., KOLAYLI, S., Antioxidant activity and phenolic acid constituents of chestnut (Castania sativa mill.) honey and propolis, Journal of Food Biochemistry, 33, 2009, 470-481.

21. POPOVA, M., SILICI, S., KAFTANOGLU, O., BANKOVA, V., Antibacterial activity of Turkish propolis and its qualitative and quantitative chemical composition, Phytomedicine, 12, 2005, 221-228.

22. KATIRCIOGLU, H., MERCAN, N., Antimicrobial activity and chemical compositions of Turkish propolis from different regions, African J. Biotech., 5, 2006, 1151-1153.

23. DURAN, N., MUZ, N., CULHA, G., DURAN, G., OZER, B., GC-MS analysis and antileishmanial activities of two Turkish propolis types, Parasitol. Res., 108, 2011, 95-105.

24. STEPANOVİ́, S., ANTİ́, N., DAKİĆ, I., ŚVABİĆ-VLAHOVİ́, M., In vitro antimicrobial activity of propolis and synergism between propolis and antimicrobial drugs Microbiol. Res., 158, 2003, 353-357.

25. KAYA, E.G., ÖZBİLGE, H, ALBAYRAK, S., Antimicrobial Activity of The Ethanolic Extract of Kayseri Propolis., Selçuk Tıp Derg, 28(4), 2012, 209-212.

26. CHAMANDI, G., OLAMA, Z., HOLAIL, H., Antimicrobial effect of Propolis From different Geographic Origins in Lebanon, Int. J. Curr. Microbiol. App. Sci., 4(4), 2015, 328 -342.

27. CASQUETE, R., CASTRO, S.M., JACOME, S., TEIXEIRA, P., Antimicrobial activity of ethanolic extract of propolis in "Alheira", a fermented meat sausage, Cogent Food \& Agriculture, 2, 2016, 1125774.

28.AL-ANI, I., ZIMMERMANN, S., REICHLING, J, WINK, M., Antimicrobial Activities of European Propolis Collected from Various Geographic Origins Alone and in Combination with Antibiotics, Medicines, 5, 2018, 2.

29. BERNARDINO, P.N., BERSANO, P.R.O., NETOC, J.F.L., SFORCINA, J.M., Positive effects of antitumor drugs in combination with propolis on canine osteosarcoma cells (spOS-2) and mesenchymal stem cells, Biomedicine \& Pharmacotherapy, 104, 2018, 268-274.

30.FRION-HERRERA， Y., DIAZ-GARCIA， A; RUIZ-FUENTES， J., RODRIGUEZ-SANCHEZ, H., SFORCIN, J.M., The cytotoxic effects of propolis on breast cancer cells involve PI3K/Akt and ERK1/2 pathways, mitochondrial membrane potantial, and reactive oxygen species generation, Inflammopharmacology, 27(5), 2018, 1081-1089.

31. ZAMMIT, E.J., THEUMA, K.B., DARMANIN, S., MURAGLIA, M., CAMILLERI-PODESTA, M.T., BUHAGIAR, J.A. CALLEJA-AGIUS, J., ADAMI, M.Z., MICALLEF, M., FRANCHINI, C., SCHEMBRI-WISMAYER, Total Content and Cytotoxicity Varies Significantly in Different Types of Propolis, RJPBCS, 4(3), 2013,1047-1058.

Manuscript received: 27.03 .2020 